\title{
PERSPEKTYWA JAKO NARZĘDZIE KOMUNIKACJI. FOTOGRAFIE MODY AUTORSTWA JEANLOUPA SIEFFA ${ }^{1}$
}

ANNA PISZCZAtKa

Wydział Nauk Humanistycznych UKSW

Faculty of Humanities, Cardinal Stefan Wyszyński University

in Warsaw

a.piszczalka@student.uksw.edu.pl

W środowisku badawczym perspektywa - obok barwy, kadru, światłocienia - uznawana jest za jedną z kluczowych strategii artystycznych, która buduje fotograficzny akt komunikacji. Celem badawczym prezentowanego artykułu jest udowodnienie, że perspektywa funkcjonuje nawet na prawach fizycznego narzędzia, podobnie jak np. aparat fotograficzny. Zyskuje ona wymiar operacyjny, sprawczy i użytkowy.

Perspektywa definiowana jest słownikowo jako wizualna metoda rozmieszczania elementów przedstawienia w taki sposób, który wywołuje złudzenie postrzegania ich w analogicznych stosunkach przestrzennych, $\mathrm{w}$ jakich widzimy te komponenty w rzeczywistości. Zatem za pośrednictwem tego środka wyrazu następuje zobrazowanie trójwymiarowych przedmiotów na dwuwymiarowej płaszczyźnie. Ujęcie perspektywiczne eksponuje obecność wielu następujących po sobie planów, które budują wrażenie głębi. Istnieją trzy rodzaje perspektyw ${ }^{2}$ - pierwotnie związanych

${ }^{1}$ Artykuł powstał na podstawie rozprawy licencjackiej napisanej pod opieką naukową dr Agnieszki Smagi na kierunku Kulturoznawstwo (Wydział Nauk Humanistycznych UKSW) i obronionej w 2019 roku.

2 Perspektywa [hasło], [w:] Słownik terminologiczny sztuk pięknych, red. K. Kubalska-Sulkiewicz, M. Bielska-Łach, A. Manteuffel-Szarota, Warszawa 2005, s. 308. 
z malarstwem - linearna (geometryczna), barwna ${ }^{3}$ i powietrzna ${ }^{4}$. A wszystkie one zaadaptowane zostały z powodzeniem przez późniejsze medium fotografii. Perspektywa linearna polega na pozornym zmniejszaniu się przedmiotów w miarę ich oddalania się od oka obserwatora oraz na iluzorycznej zbieżności wszystkich prostych na osi horyzontu. Istnieje kilka wariantów tej perspektywy i można je wyodrębnić na podstawie usytuowania na płaszczyźnie obrazu punktu zbiegu linii prostopadłych względem widnokręgu. Miejsce styku prostych może znajdować się: w partii dolnej przedstawienia (układ z lotu ptaka), w części górnej (ujęcie żabie), z boku (perspektywa boczna), poza obrazem (ukośna) ${ }^{5}$.

W ujęciu historycznym można zauważyć, że wielokrotnie próbowano zdefiniować proces widzenia i odwołujące się do niego zagadnienie perspektywy. W XV wieku Leon Battista Alberti, mówiąc o perspektywie malarskiej, wykorzystał wiedzę matematyczną, w szczególności koncepcję rzutowania ${ }^{6}$. Widok realnej przestrzeni był rzutowany z geometryczną precyzją na

3 Perspektywa barwna polega na wykorzystywaniu odpowiednich zestawień kolorystycznych, tak aby wywoływały one wrażenie głębi i przestrzeni, np. ciepłe kolory „przybliżają” namalowany przedmiot, a zimne barwy „oddalają” przedstawienie. Sugerowane zagadnienie nie będzie rozwijane w prezentowanym artykule, ponieważ analiza dotyczy materiału fotograficznego czarno-białego.

4 Perspektywa powietrzna - przywołuje zależność znaną z percepcji ludzkiej. Człowiek postrzega przedmioty jako blaknące, malejące i coraz mniej wyraźne wraz z ich oddaleniem od oka obserwatora. Podążając tym tropem wnioskowania, dalekie elementy wydają się mieć szaroniebieską tonację, o mniejszym zauważalnym kontraście i zarysie.

5 W odniesieniu do sztuki średniowiecznej stosuje się termin „perspektywy odwróconej": zgodnie z panującym ówcześnie światopoglądem przedmioty i osoby z planu dalszego były większe niż formy znajdujące się na pierwszym planie obrazu.

6 Artysta w swoim traktacie o malarstwie precyzyjnie rozrysował problem perspektywy, wyznaczył trzy rodzaje promieni: zewnętrzne, wewnętrzne i promień centryczny, które tworzyły trójkąt, a dzięki temu w oku malarza powstawał obraz. Ów trójkąt artysta porównywał do „piramidy procesu patrzenia”, gdzie wierzchołek znajdował się w oku obserwatora, podstawą była widzialna powierzchnia, a jej ściany boczne tworzyły promienie widzenia. Zob. Myśliciele, kronikarze i artyści o sztuce. Od starożytności do 1500 r., wyb. i oprac. J. Białostocki, Warszawa 1978, s. 344-349. 
płaszczyznę obrazu, która stawała się dla teoretyka „otwartym oknem”" Analogiczną postawę odbiorczą względem zagadnienia perspektywy reprezentował Leonardo da Vinci, który porównywał obraz do szklanej ściany (pariete di vetro) ${ }^{8}$. Założył, że perspektywa jest dokładnym odzwierciedleniem rzeczywistości, zgodnym z naszym jej widzeniem. Jednak malarzowi nie wystarczył już tylko „świat widziany w poprawnej perspektywie linearnej”, dążył on do oddania „prawdziwszej głębi”. Da Vinci eksponował malarską plastyczność ciał, która, wraz z tłem, tworzyła iluzję wchodzenia w głąb płaszczyzny. A efekt ten uzyskiwał za pomocą trzech opisanych wyżej perspektyw, czyli zmniejszania kształtów, ograniczania kontrastów oraz wygaszania kolorów. Dodatkowo da Vinci uzyskiwał trójwymiarowość kreowanych postaci, stosując słynne sfumato, czyli zacieranie granic form malarskich.

Dopiero historyk sztuki Erwin Panofsky sprzeciwił się przywołanemu wyżej renesansowemu przekonaniu, że narzędzie perspektywy jest obiektywnym sposobem odzwierciedlania postrzeganego świata. $\mathrm{W}$ rozprawie Perspektywa jako "forma symboliczna" przedstawił tezę, że środek ten jest tylko konwencjonalną realizacją, która, choć służy odwzorowaniu rzeczywistości, to jednak zawiera szereg nieprawidłowości. Przestrzeń konstruowana za pomocą tej umownej zasady posiada bowiem dystorsje, wobec czego relacje zaistniałe pomiędzy światem przedstawionym a postrzeganym nie są obiektywne i nie przedstawiają prawdziwego układu przestrzennego. Dla Panofsky'ego każda różnica wizualna występująca między kopią obrazową a przedstawieniem realnym była dowodem na to, że stosowanie perspektywy linearnej niezupełnie odwzorowuje relacje istniejące pomiędzy światem rzeczywistym a namalowanym. Można powiedzieć, że już wtedy perspektywa okazywała się narzędziem użytkowym nie w pełni przezroczystym. Panofsky w swoim studium nawiązywał do myśli Ernsta Cassirera i jego koncepcji form symbolicznych. W poglądzie niemieckiego filozofa symbol pełnił rolę medium między podmiotem a postrzeganym przedmiotem i był warunkowany tymi dwoma komponentami procesu zapośredniczenia. Filozof słusznie zauważył, że człowiek nie żyje tylko w świecie fizycznym,
7 Ibidem.
8 Ibidem.
9 Ibidem, s. 22. 
ale również symbolicznym, na który składają między innymi język, mit, sztuka i religia ${ }^{10}$.

Panofsky uznał z kolei, że symbol umożliwia zawiązywanie relacji między zmysłowością a duchowością oraz między tym, co ogólne, a tym, co jednostkowe. Dlatego perspektywa - rozumiana jako forma symboliczna - była warunkowana historycznie, kulturowo, można również dodać: użytkowo (tak jak narzędzie), okazując się zjawiskiem zmiennym, ewoluującym ${ }^{11}$. Nie stanowiła zatem jedynie zasady przedstawiania trójwymiarowego świata w dwóch wymiarach, ale była kształtowana przez różnorodne poglądy naukowe, style artystyczne, filozofię itp. Panofsky potraktował jednak perspektywę jako stosunkowo stabilną formę, kształtowaną przez otaczające ją zjawiska. Nie zauważył, że ona sama buduje również kontekst kulturowy, społeczny i polityczny, czyli jest aktywnym narzędziem.

Problem perspektywy, choć wydawało się, że został technicznie nakreślony, to nadal stwarzał pewne trudności w zaaplikowaniu teorii do praktyki, czyli w ukazywaniu przestrzeni na dwuwymiarowej powierzchni obrazu. A pojawienie się w XIX wieku fotografii z jednej strony potwierdziło sugerowaną wyżej zasadność stosowania malarskich zasad perspektywicznych, z drugiej - tę konwencję podważyło. Wydawało się, że wynaleziona technika pozwoli rozwiązać problem mimetyczności i „przechwycić” rzeczywistość, przekształcając ją w obraz. Wynalazek ten potwierdził przypuszczenie,

10 E. Cassirer, Esej o człowieku. Wstęp do filozofii kultury, tłum. A. Staniewska, przedm. B. Suchodolski, Warszawa 1998, s. 69. Dalej czytamy: „[...] człowiek nie potrafi się już bezpośrednio ustosunkować do rzeczywistości. Nie może jak gdyby stanąć z nią twarzą w twarz. W miarę jak symboliczna działalność człowieka robi postępy, rzeczywistość zdaje się cofać. Zamiast zajmować się rzeczami samymi $\mathrm{w}$ sobie, człowiek w pewnym sensie ustawicznie sam z sobą rozmawia. Tak bardzo owinął się w formy językowe, w obrazy artystyczne, w mityczne symbole lub religijne obrządki, że nie potrafi już niczego zobaczyć ani poznać inaczej, jak za pośrednictwem tego sztucznego środka".

11 W koncepcji Panofsky'ego perspektywa antyczna odpowiadała subiektywnemu widzeniu, natomiast perspektywa renesansowa ujmowała przestrzeń obrazu w sposób matematyczny, czyli obiektywizowała doznanie subiektywne. E. Panofsky, Perspektywa jako "forma symboliczna", tłum., wstęp i posłowie G. Jurkowlaniec, Warszawa 2008, s. 51-53. 
że status rzeczywistości realnej koresponduje z naszym jej widzeniem. Okazało się jednak, że fotografia nie była idealnym odzwierciedleniem świata postrzeganego. Aparat fotograficzny pozwolił zbliżyć się do ukazywania prawdy o świecie, jednak obiektyw, pozycja fotografa czy usytuowanie kamery mogły pokazywać w nieobiektywny sposób rzeczywistość. Fotograficzne spojrzenie chwytało tylko mały fragment rzeczywistości, wybrany arbitralnie przez artystę. Zobrazowany moment był „zamrożeniem ruchu” i dotyczył faktów, które się wydarzyły. Nieco późniejsze pojawienie się różnych obiektywów proponowało nawet zniekształcone, można powiedzieć: surrealistyczne punkty widzenia przedmiotu. Dlatego perspektywę należałoby traktować (analogicznie jak aparat fotograficzny czy obiektyw) jako właśnie operacyjne narzędzie użytkowe, dokonujące wielu zmian w obszarze i funkcjonowaniu antroposfery.

Perspektywa - rozumiana na prawach narzędzia - jest, jak postaram się wskazać w niniejszym artykule, także komunikatem. Fotograf dzięki odpowiednio dobranej perspektywie może wskazać najważniejsze elementy ujęcia, wywołać u odbiorcy pozory uczestnictwa w przedstawieniu, wpłynąć na jego emocje i wrażenia. Proces komunikacji zachodzi między fotografem a odbiorcą, formą-pośrednikiem jest natomiast obraz.

Fotografia mody, mająca charakter przede wszystkim reklamowy, z założenia winna odwzorowywać rzeczywistość w taki sposób, aby odbiorca identyfikował się z przedstawianą postacią, by uwierzył, że istnieje ona naprawdę. Zatem fotografia mody tworzona była po to, aby dostarczać iluzji realności, ponieważ odbiorca chciał wierzyć, że odnosi się ona do prawdziwych zdarzeń. Następnie oglądający powinien odczuwać potrzebę posiadania sfotografowanych ubrań i akcesoriów, by w efekcie je kupić. Mechanizm jest zatem prosty. François Soulages pisał: „słusznie zatem pożąda się realnego, które, w konsekwencji, zostaje kupione oraz skonsumowane"12. W omawianym kontekście należałoby traktować fotografię mody jako coś, co zostało odegrane. Ujęcie jest fragmentem rzeczywistości celowo wybranym przez fotografa. Patrząc na zdjęcie, możemy powiedzieć, że kadr ten został zainscenizowany i wykonany przed aparatem oraz przed

12 F. Soulages, Estetyka fotografii. Strata i zysk, tłum. B. Mytych-Forajter, W. Forajter, Kraków 2012, s. 18-23. 
fotografem $^{13}$. Zaaranżowany spektakl ma nakłonić oglądającego do zakupu prezentowanego artykułu. W analizach badawczych nie można również pominąć ingerencji technicznej, bowiem obraz, zapisywany na negatywie, poddany jest manipulacjom już na poziomie procesu fotografowania: mechanicznego i automatycznego (m.in. intencja fotografa, rodzaj obiektywu czy właściwości techniczne aparatu). Następnie obraz ulega obróbce w ciemni lub za pomocą programów cyfrowych. W konsekwencji pokazana na zdjęciu rzeczywistość sfotografowana ulega wielokrotnemu zafałszowaniu: mechanicznemu i twórczemu. Paradoksalnie, w perspektywie odbiorczej przedstawienie utrzymuje nadal silny związek z realnością. Fotografia jest zatem narzędziem ambiwalentnym: może z jednej strony ujawniać prawdę, z drugiej - ją zakrywać. Wskazane cechy decydują o tym, że zdjęcie odzwierciedla i jednocześnie pobudza potrzeby ludzkie. Za pośrednictwem fotografii można nawet zrozumieć zmiany, jakie dokonują się w świecie jej współczesnym: „najdoskonalsza modowa fotografia to fotografia czegoś więcej niż mody"14. Zatem staje się ona środkiem komunikacji i kreuje znaczenia na poziomie życia codziennego, wiedzy/władzy, obyczajowości i kultury. Obrazy fotograficzne są wszechobecne, pojawiają się w strefie publicznej i prywatnej, dotyczą poziomu zbiorowego i jednostkowego ${ }^{15}$.

Na przełomie lat 70. i 80. XX wieku Vilém Flusser w swoim studium $K u$ filozofi fotografii stwierdził, że fotografia spowodowała fundamentalną zmianę cywilizacyjną. Ewolucja ta miała polegać na tworzeniu się społeczeństwa zdominowanego przez obrazy techniczne, które stanowiły „obliczeniowe pojęcia”. Flusser interpretował te obrazy za pomocą „technicznej imaginacji”, która objaśniała znaczenia symboli ${ }^{16}$. Aparat fotograficzny jest elementem fundamentalnym w filozofii fotografii Flussera. Sprzęt stanowi narzędzie-pośrednik między fotografem a odbiorcą, buduje model komunikacji oraz posiada silną tendencję do podporządkowania sobie czło-

13 Ibidem, s. 21-23.

14 S. Sontag, The Eye of Avedon, „Vogue” (UK) 1978, Vol. 9, s. 12.

$15 \mathrm{~W}$ wirtualnej przestrzeni zdjęcia wywołują dodatkowo interakcje odbiorcze, podtrzymują kontakty międzyludzkie, budują sieci zależności społecznych, również ekonomicznych i politycznych.

16 V. Flusser, Ku filozofii fotografii, tłum. J. Maniecki, przedm. P. Zawojski, Warszawa 2015, s. 22. 
wieka. Proces przekazu zostaje zapośredniczony przez aparat, uznany za sprawcze, mechaniczne narzędzie. W analogiczny sposób można rozumieć perspektywę. Ona również pośredniczy w akcie komunikacji: buduje, zmienia i nadaje kierunek przeżyciom, interpretacjom, sposobom użytkowania - tylko nasze percepcyjne przyzwyczajenie nie pozwala postrzegać perspektywy jako narzędzia obrazowego i manipulacyjnego. Dodatkowo sam status narzędzia czyni go przezroczystym wizualnie, a w efekcie również funkcjonalnie. Zatem perspektywa, ustanawiając procesy poznawcze, sama się w nie wtapia. Być może stąd uznajemy ją za „coś” neutralnego, naturalnego, dajemy się zwieść generowanej przez nią iluzji trzech wymiarów. $\mathrm{Z}$ tego powodu zasługuje ona na głębszy namysł badawczy, charakterystykę oraz uwzględnienie jej narzędziowej (kodująco-medialnej) struktury. Dlatego w prezentowanym artykule czasowniki sprawcze i operacyjne przyporządkowane zostały również perspektywie.

Na gruncie badań odnoszących się do komunikacji wizualnej zauważamy, że narzędzia odgrywają istotną rolę. Mogą one przekształcać oczekiwania i nawyki społeczne, a nawet schematy rozumienia i poznania. W komunikacie obrazowym perspektywa-urządzenie pełni trzy funkcje: operacyjną, sprawczą i użytkową. Zmiennie modeluje świat przedstawiony. Sprawia, że komunikat, dzięki zastosowaniu nietypowego punktu widzenia, staje się bardziej intrygujący, tajemniczy, zwraca na siebie uwagę odbiorcy, który w efekcie kupuje sfotografowane ubranie. Aspekt operacyjny perspektywy umożliwia wykorzystanie kodów i symboli, gdzie myślenie odbiorcze opiera się na skojarzeniach, zapamiętywaniu, uogólnianiu czy uszczegóławianiu. W następstwie przeprowadzonych operacji tworzone są nowe pojęcia, które uczestniczą przy każdej kolejnej percepcji świata. Narzędzie perspektywy może przekazywać informacje na różnych płaszczyznach i tworzyć nowe konwencje. Jest ono ucieleśnionym kodem, który w konstrukcji fotografii wyznacza schematy patrzenia ${ }^{17}$. Dzięki perspektywie widzimy inaczej,

${ }_{17}$ Zagadnienie perspektywy analizowane w kontekście aktu percepcji jest przedmiotem zainteresowania wielu dziedzin nauki, również rozwijającej się współcześnie neuroestetyki. Ta metoda badawcza, zaproponowana przez Semira Zekiego, kontynuowana jest w Polsce m.in. przez Piotra Francuza, Włodzisława Ducha, Piotra Przybysza i innych. Pierwszy - rodzimy - badacz, powołując się na zagraniczne źródła naukowe, z jednej strony wyróżnił neuropoznawcze mechanizmy 
a w konsekwencji - w różny sposób myślimy i działamy. Perspektywa buduje wrażenie głębi, może przekształcać obraz świata rzeczywistego, zmieniać znaczenia czy tworzyć złudzenia optyczne. W procesie widzenia dokonuje się interpretacja powierzchni obrazu dwuwymiarowego, który stanowi przeistoczenie trójwymiarowego świata. Aparat i perspektywa stają się narzędziem kreacji w rękach fotografa. Podążając za tą myślą, decydująca wydaje się relacja między człowiekiem a sprzętem. Potwierdza to wizję Flussera, dla którego tak istotna była struktura przekazu i mechanizmy rządzące komunikacją.

Gwałtowny rozwój branży modowej w połowie XX wieku wpłynął na pojawienie się nowych twórców ze świeżymi pomysłami - i do nich z pewnością należał Jeanloup Sieff. Ten innowacyjny artysta polskiego pochodzenia urodził się w Paryżu w 1933 roku, a zmarł w roku 2000. Fotografował od wczesnej młodości, ale jego kariera nabrała tempa dopiero, gdy dołączył w 1958 roku do prestiżowej agencji fotograficznej „Magnum”. Pracował m.in. dla czasopism: „Esquire”, „Vogue”, „Harper’s Bazaar” i „Elle”. Zdobył wiele nagród ${ }^{18}$, fotografował gwiazdy, wśród portretowanych byli: Yves SaintLaurent, Twiggy, Jane Birkin, Rudolf Nureyev i Alfred Hitchcock ${ }^{19}$. Sieff jest jednym z najważniejszych i najbardziej uznanych międzynarodowych fotografów ostatniego pięćdziesięciolecia. Analizując jego zdjęcia, możemy

percepcji, które są odpowiedzialne za „świadomość uporządkowania rzeczy wzdłuż trzeciego wymiaru", z drugiej strony wskazał jednoznaczne wskaźniki głębi, wśród których znalazła się właśnie perspektywa. Francuz uznał, że te wizualne wyznaczniki stanowią własność obrazu, ale ich interpretacja jest już cechą obserwatora, a ściślej: jego „zdolności postrzegania rzeczy jako tożsamych niezalenie od warunków percepcyjnych”. P. Francuz, Głębia, [w:] idem, Imagia. W kierunku neurokognitywnej teorii obrazu, Lublin [cop. 2013], s. 221-230. Analiza fotografii mody w kontekście neuroestetyki, choć wydaje się ciekawa badawczo, nie mieści się jednak w formule rozważań, która przyjęta została w prezentowanym artykule.

${ }_{18}$ Między innymi: Prix Niepce (1959), Chevalier des Arts et Lettres (1981) oraz Grand Prix National de la Photographie (1992).

19 Zob. Jeanloup Sieff: 40 Years of Photography; 40 Jahre Fotographie; 40 ans de photographie, ed. S. Philippi, Kolonia 2010. 
odwołać się do Flusserowskiej filozofii fotografii. W tej koncepcji sprzęty techniczne - aparat i obiektyw fotograficzny - były elementami determinującymi obrazy. W branży fotograficznej funkcjonuje uproszczony podział obiektywów na: standardowe (pozwalają na otrzymanie zdjęcia o geometrii i perspektywie najbardziej zbliżonej do ludzkiego postrzegania świata), teleobiektywy (wprowadzają duży stopień przybliżenia oraz kompresję przedmiotów z dalekiego planu) oraz szerokokątne (dają większe pole widzenia, proste linie są nieco wydłużone). Obiektywy o krótszej ogniskowej (tak zwane szerokokątne) cechują się dużą głębią ostrości i stosowane są dla oddania krajobrazów, architektury i zamkniętych pomieszczeń - w tym przypadku przedmioty z drugiego planu wydają się równie wyraźne jak z pierwszego. Sieff zdecydował się na fotografowanie mody za pomocą tych obiektywów, co w latach 60 . było niekonwencjonalne. Początkowo fotografie Sieffa nie spotkały się z entuzjastycznym przyjęciem, towarzyszyły im kontrowersyjne opinie. Krytycy zauważyli, że ubranie przestało być najważniejszym elementem zdjęcia, a sylwetka została zniekształcona, czasem nawet modelka stawała się słabo widoczna. $Z$ takim rodzajem przedstawienia spotykamy się $\mathrm{np}$. w fotografii zatytułowanej Mode lointaine (Odległa moda) (il. 1.).

Można przypuszczać, że w tym przypadku fotograf chce pokazać swoje zdystansowanie do „wyglądowego" świata mody. Sieff stara się dotrzeć głębiej, pod powierzchnię obrazu, przedstawić własną wizję rzeczywistości. Nie wystarcza mu pokazywanie wyłącznie ubrań: modelka ma nie tylko zaprezentować i odegrać określoną rolę, ale również zaskoczyć widza swą obecnością. Dlatego na fotografii jej postać jest tylko małym elementem rozbudowanej graficznej kompozycji. Na zdjęciu zaproponowano bardzo starannie przemyślany układ: cienkie linie karuzeli kontrastują z wagonikami i drobną postacią modelki, która w ten sposób staje się słabo widoczna. Zarys sylwetki „nie gubi się” jednak w rozrywkowym świecie wesołego miasteczka. Opisany układ kompozycyjny jest rozwiązaniem bardzo nowatorskim. Głębia ostrości jest duża, obejmuje całą kompozycję, modelka jest tak samo ostra jak tło. Postać pozostaje jedynym żywym elementem zdjęcia, koło jest starannie zatrzymane w wybranej fazie ruchu. Fotograf pozwala sobie na pewien rodzaj gry z odbiorcą: ruch i dynamika oraz spiralna konstrukcja karuzeli ma zaprowadzić oko widza do głównego celu przedstawienia, czyli sylwetki modelki. Mistrzowska perswazja fotografa 


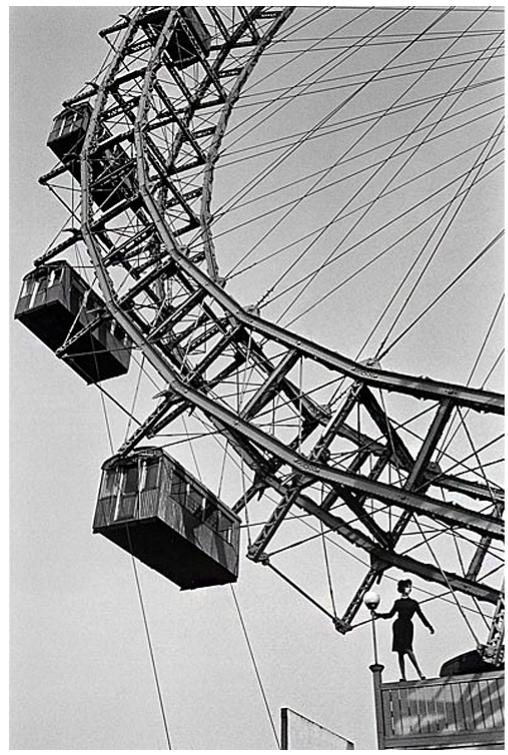

Il. 1. Jeanloup Sieff, Mode lointaine, Wiedeń 1961

kieruje wzrok odbiorcy od mechanicznej, ogromnej konstrukcji do ożywionej, małej postaci. Odbiorca przesuwa wzrok po fotograficznej powierzchni, podążając ścieżkami sugerowanymi przez jej strukturę. Oglądający, idąc za sugestiami Sieffa, wśród krzywych linii pozornego ruchu koła dociera do punktu głównego zdjęcia. Fotograf był często krytykowany za brak zainteresowania ubraniami, które pokazywał. Tymczasem wizualny kontrast małej postaci i dużego koła karuzeli rodzi dystans odbiorczy, który, paradoksalnie, staje się podstawą pożądania prezentowanej sukienki. Podejście to może wydawać się sprzeczne z ideą sprzedaży, ale w rzeczywistości kryje się za nim wiedza psychologiczna. Nadawca komunikatu tylko pozornie nie jest zainteresowany pokazaniem ubrania. Faktycznie natomiast poprzez zastosowanie żabiej perspektywy buduje potrzeby konsumenckie. Perspektywa wykorzystana zostaje jako narzędzie sprzedażowe. Widz może swobodnie tworzyć w wyobraźni zarówno dalszą część planu przedstawienia, jak i snuć fantastyczne historie związane $\mathrm{z}$ widoczną postacią.

W przypadku fotografii zatytułowanej La defense (il. 2), obraz również nie jest jedynie automatyczną rejestracją rzeczywistości, ale przedstawia 


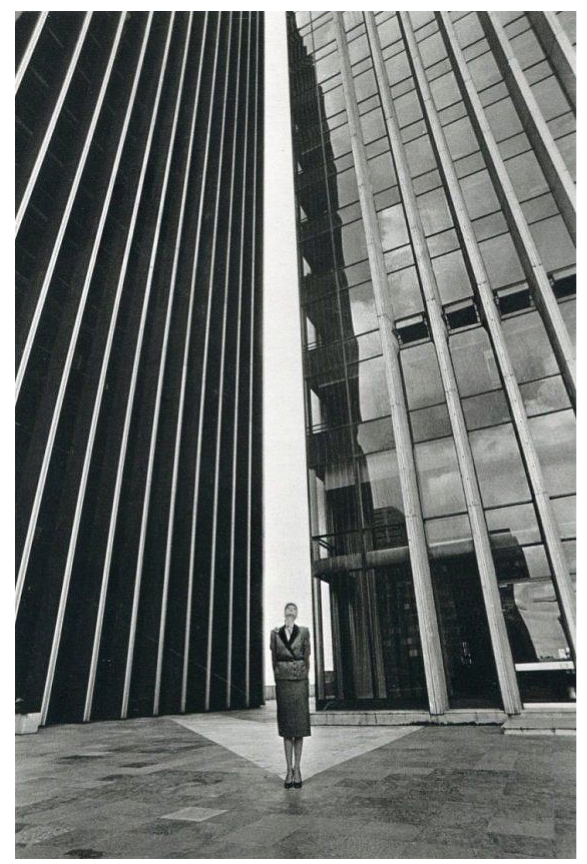

Il. 2. Jeanloup Sieff, La defense, Paryż 1979

autorską wizję świata. W języku francuskim la defense oznacza „obronę”. Słowo to odnosi się również do nowoczesnej dzielnicy Paryża, nazywanej właśnie „La Defense”, która jest głównym centrum biznesowym i w której wykonano prezentowane zdjęcie. Ta przestrzeń miejska składa się z futurystycznych, przeszklonych wieżowców, a także z awangardowych rzeźb i instalacji. Fotograf, w sposób charakterystyczny dla swojego stylu, dba o przemyślany kadr - geometryczny układ oraz brak przypadkowych elementów przedstawienia. Kompozycja fotografii wskazuje na duże umiejętności i doświadczenie oraz wyczucie twórcy, ponieważ trudno precyzyjnie ustawić scenę aparatem dalmierzowym przy tak szerokim obiektywie. Perspektywa żabia kreuje przestrzeń, która prowadzi wzrok odbiorcy na modelkę, mimo że stanowi ona mały fragment kompozycji. Użycie perspektywy żabiej powoduje „wyciągnięcie” sylwetki kobiety oraz tworzy świetlistą przestrzeń między budynkami. Owa jasna powierzchnia silnie kontrastuje z przedstawianą postacią, a w efekcie to na niej koncentruje się 
uwaga odbiorcy. Na omawianej fotografii narzędzie perspektywy buduje monumentalność postaci. Sieff, wykorzystując obiektyw szerokokątny, osiąga dystans między aparatem a modelką. Fotograf tworzy idealną symbiozę światła oraz perfekcyjny balans skali szarości. Poprzez opisany typ perspektywy, czarno-białą fotografię, śmiały kadr, kontrast światłocieniowy, proste formy i struktury architektoniczne, układ kolejnych planów - Sieff buduje kompozycję jednocześnie realistyczną i surrealistyczną. Ujęcie fotograficzne cechuje duża precyzja i perfekcja, które można zestawić z przedstawionym typem kobiety sukcesu. Środki artystycznego wyrazu budują „surową”, „zdystansowaną” estetykę, która dobrze koresponduje ze zobrazowanym tematem.

Sugerowane powinowactwa budowane są również przez sposób ukazania modelki. Sieff decyduje się na umieszczenie postaci w centrum zdjęcia. Kobieta unosi głowę i wzrok ku górze. Układ ten sugeruje bliski i zarazem daleki świat zawodowych aspiracji. Ważna staje się przestrzeń między budynkami, która z trójkątem przedstawionym na posadzce tworzy kształt strzały. Symbolika tego rodzaju przedstawienia oznacza kobiecą siłę, doskonałość, dążenie do celu. W ten sposób Sieff chce zaznaczyć oczekiwania oraz ambicje bizneswoman. Perspektywa okazuje się również efektywnym narzędziem komunikacji społecznej, wykraczając tym samym poza sprzedaż ubrań. W tym przypadku zdjęcie opowiada historię przedstawionej na niej kobiety - za pośrednictwem analizowanego przedstawienia wskazano zatem kontekst społeczno-obyczajowy, w jakim powstał obraz. Przypomnijmy, że właśnie w latach 70. kobiety kolejny raz walczyły o równouprawnienie (na rynku pracy, w zakresie wynagrodzeń czy piastowania kierowniczych stanowisk) oraz poruszały tematy dotyczące seksualności. Sugerowana na zdjęciu osobowość modelki, jej mimika, postawa - wszystkie te czynniki mają ogromne znaczenie w budowaniu wizerunku bizneswoman, a tym samym w odbiorze zdjęcia. Zastosowana perspektywa ma sprawić, że kobieta-odbiorca będzie chciała utożsamić się z modelką na zdjęciu, czyli być przedsiębiorcza, bogata i piękna, a dążąc do tego... zakupi prezentowane na zdjęciu ubranie. Pragnienia kobiece podsycane są prawami rynku i odwrotnie. Emocje, komunikacja i ekonomia wzajemnie się regulują. Niekonwencjonalne ujęcia pozwalają Sieffowi na osiągnięcie wymienionych wyżej celów. Narzędzie perspektywiczne konstruuje skuteczne kody komunikacyjne, które mogą odnaleźć także swe przełożenie ekonomiczne. 
Przypisanie fotografii kontekstu społeczno-kulturowego sprawia, że kobieta-odbiorca bez przeszkód może utożsamić się z modelką. Pokazana na zdjęciu sytuacja awansu społecznego wpływa stymulująco na odbiorcę, zobowiązuje go do zaangażowania się w kwestie równouprawnienia kobiet - jakby zgodnie z zasadą wyłożoną przez Keith Moxley: „obraz winien więc być badany nie tylko przez wzgląd na niego samego, ale również ze względu na szeroki zakres skutków społecznych, które może wygenerować" ${ }^{20}$.

Sieff dąży to tego, aby odbiorca jak najdłużej zatrzymał wzrok na fotografii, a im dłużej trwa analityczna percepcja obrazu, tym bardziej znaczący staje się przekaz. Fotograf zaobserwował, że zdjęcie mody wyzwala w odbiorcy pożądanie i konstruuje znaczenie „sezonowe”, natomiast zdjęcie „w ogóle” ustanawia semantykę ponadczasową. W drugim przypadku artysta zakłada możliwość uchwycenia istoty rzeczy. W konsekwencji odbiorca zaczyna wierzyć w świat istniejący na obrazie, odrywa się od rzeczywistości i zatraca w przedstawieniu. Zastosowanie perspektywy żabiej, czarno-białych kolorów oraz kontrastu światłocieniowego stwarza pozory uczestnictwa „w zdjęciu”.

W fotografii zatytułowanej Courrèges, fundacja Maeght (il. 3) następuje połączenie użytkowości i sztuki, rzeczywistości i fantazji. Tytuł informuje nas, że sukienkę prezentowaną na zdjęciu zaprojektował André Courrèges. Fotografię wykonano w muzeum sztuki nowoczesnej Fundacji „Maeght”, mieszczącej się w Saint-Paul-de-Vence. Kontrast wizualny wprowadzony między „kosmicznym strojem” modelki a rzeźbą Giacomettiego kieruje wzrok odbiorcy na drugi plan obrazu, na którym znajduje się postać kobiety. Zastosowana perspektywa wprowadza grę pomiędzy pierwszym i drugim planem przedstawienia. W przeciwieństwie do dwóch poprzednich analizowanych zdjęć w tym przypadku fotograf wykorzystał stosunkowo małą wartość przesłony w obiektywie szerokokątnym. Ten zabieg techniczny zbudował dyskretne rozmycie rzeźby na pierwszym planie i sprawił, że widz najpierw spostrzega plan drugi. Modelka stoi w wystudiowanej pozie i podnosi okulary. Układ ten stwarza wrażenie zatrzymania w ruchu. Wydaje się, że fotografowana postać czuje pewien dyskomfort, przybiera nienaturalną pozę. Uwagę widza przykuwa ekscentryczne białe ubranie

20 M. Bogunia-Borowska, Fotospołeczeństwo. Społeczno-kulturowe konteksty dyskursu o społeczeństwie, [w:] Fotospołeczeństwo. Antologia tekstów z socjologii wizualnej, red. M. Bogunia-Borowska, P. Sztompka, Kraków 2012, s. 43. 


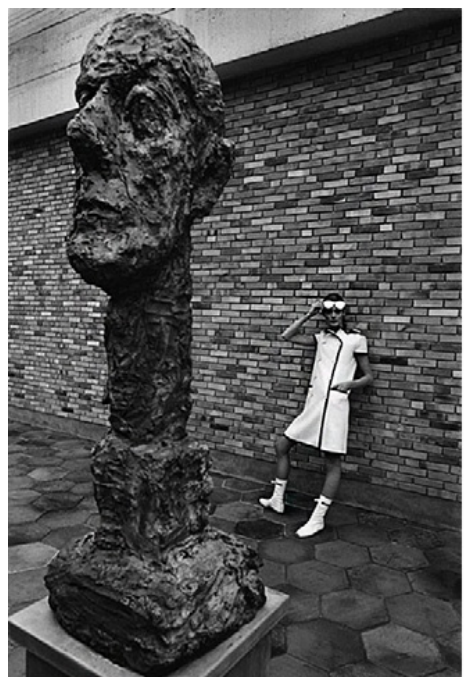

Il. 3. Jeanloup Sieff, Courrèges, fondation Maeght, Saint-Paul-de-Vence 1965

i buty, które to oba komponenty garderoby kontrastują z chropowatością i surowością rzeźby. Modelka - podnosząc okulary - patrzy podejrzliwie w stronę obiektywu aparatu, dlatego odbiorca ma wrażenie, że zachodzi pomiędzy nim a postacią pewna szczególna - spersonalizowana, ale niepokojąca - relacja. Fotograf, stosując rozmyty pierwszy plan i perspektywę ukośną, zachęca widza do wejścia w przedstawienie. Odbiorca ma poczucie, że „wtargnął” w świat ukazany na zdjęciu i stał się elementem prywatnej przestrzeni osoby fotografowanej. Równocześnie towarzyszy mu poczucie „ulotności chwili”, uchwyconej okiem fotografa, a o zjawisku tym mówił sam Sieff w następujących słowach:

Fotografia, niestety, nigdy nie odda wiernie rodzącego się uczucia, ale choć tak niedoskonała, pozostaje naiwną próbą wyrwania się z rąk śmierci. Chcę zatrzymać czas na ulotnym spojrzeniu, nagłym olśnieniu, szczęśliwej chwili, które odchodzą bezpowrotnie, ale na fotografii będą istnieć, jak zgasłe przed tysiącami lat gwiazdy, których światło dociera teraz do nas, żeby powiedzieć nam, czym były ${ }^{21}$.

${ }^{21}$ Jeanloup Sieff1987 Part 1, YouTube, 5.02.2011; 0:13-0:39, https://www.youtube. com /watch?v=v4Pm9aN_JIQ [dostęp: 14.05.2019]; tłumaczenie własne - A.P. 
Użycie niekonwencjonalnej perspektywy winno zaskoczyć odbiorcę i wywołać w nim niespodziewane oczekiwania. Zastosowane strategie powodują, że widz daje się wciągnąć w perspektywiczną grę i uczestniczy aktywnie w odbiorze fotografii. Użyta forma sukienki, okulary, poza modelki, ale przede wszystkim boczna perspektywa sprawiają, że zdjęcie staje się zagadkowe. Fotografia zawiera w sobie nastrój surrealistyczny, który zaciekawia i pobudza do myślenia bardziej niż realistyczne przedstawienie. W ten sposób rozwiązanie artystyczne integruje się z użytkowym, dodając mu, z jednej strony, wymiaru funkcjonalnego, $\mathrm{z}$ drugiej - zapewniając ponadczasowe trwanie. Aparat w rękach Sieffa staje się narzędziem kreacji, co oznacza: „widzieć ciągle w nowy sposób, [...] aby wytwarzać nowe sytuacje będące nośnikiem informacji”"22.

Sieff fotografii zatytułowanej Australijska Maggie Eckardt (il. 4) kreuje ponownie dwa kontrastowe plany. Postać występująca na pierwszym z nich tworzy rodzaj obramowania wizualnego dla modelki z drugiego planu. Kolejną ramę kompozycyjną budują drzwi szklarni. Ten typowy dla Sieffa sposób przedstawienia sprawia, że pierwszy plan jest tylko uzupełnieniem drugiego. Taka organizacja powierzchni obrazu wizualnego wyznacza odbiorcy przejścia: od punktu widzenia zewnętrznego do wewnętrznego i odwrotnie. Zdjęcie przedstawia pewną rzeczywistość, wobec której odbiorca przyjmuje początkowo pozycję zewnętrzną, a zatem postronnego obserwatora. W tym przypadku przedstawienie staje się widokiem przez okno, finestra aperta Albertiego czy pariete di vetro Leonarda da Vinci. Stosunkowo szybko obserwator zostaje wciągnięty - między innymi za pośrednictwem wewnętrznych ram przedstawienia czy wirującego wzoru na spodniach modelki - w przedstawienie. Ponadto ramy zaznaczają na zdjęciu granice układów, które tworzą grę planów, nadając prezentacji charakter semiotyczny ${ }^{23}$. Wyeksponowanie ramy kadru fotograficznego sygnalizuje, że świat przedstawiony nie jest naturalny, lecz wykreowany, sztuczny, nierealny. Został on intencjonalnie skonstruowany przez artystę, czyli winien być interpretowany symbolicznie. Zdjęcie jest zbudowane na grze planów

22 V. Flusser, op. cit., s. 55.

23 Fragment artykułu powstał w oparciu o lekturę: B. Uspienski, Poetyka kompozycji. Struktura tekstu artystycznego i typologia form kompozycji, tłum. P. Fast, Katowice 1997, s. 191-244. 


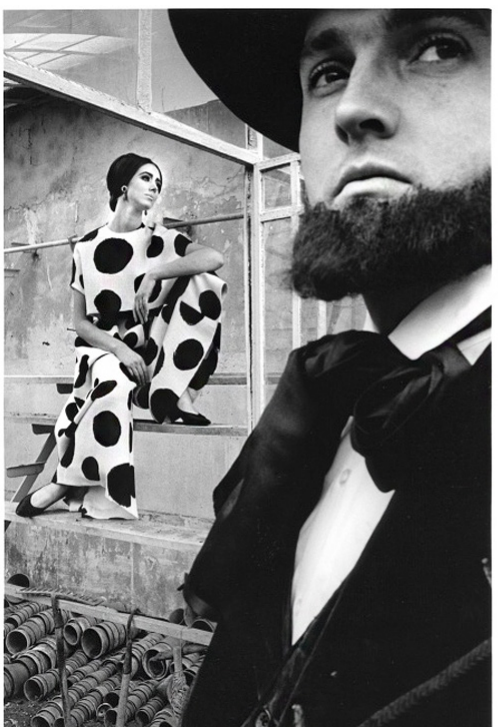

Il. 4. Jeanloup Sieff, Australian Maggie Eckardt, „Harper's Bazaar” 1964

i kontrastów kształtów oraz światłocieni. Sieff tworzy po raz kolejny dysonans między pierwszym a drugim planem: mężczyzna ma na sobie czarny garnitur z białą koszulą - natomiast kobieta jest ubrana w biały komplet w czarne kropki, same w sobie już skontrastowane. Eleganckie ubranie modelki, typowe dla lat 60., odcina się na tle obskurnych, odrapanych, pomalowanych niezdarnie ścian budynku (podobnie jak w poprzednio analizowanym zdjęciu). Najprawdopodobniej miejsce to jest szklarnią, wokół której znajdują się doniczki. One również intensyfikują wzór geometryczny umieszczony na ubraniu kobiety. Modelka przybiera typową modową pozę, wydaje się nieobecna, zdystansowana i niewzruszona. Pomimo to zdjęcie jest intensywne i naładowane emocjonalnie, uwagę widza zwraca blada twarz mężczyzny z głębokim spojrzeniem skierowanym poza kadr. Brak kontaktu wzrokowego miedzy bohaterami przedstawienia stwarza enigmatyczną atmosferę. Odbiorca, patrząc na obraz, ulega melancholii, która pobudza wyobraźnię. Sieff próbuje stworzyć kod wizualny bazujący na odczuciach, jego celem jest wywarcie wpływu na widza, chce go poruszyć oraz dać mu przestrzeń do przemyśleń. 
Zdjęcie wygląda na przypadkowo uchwycony kadr, tymczasem faktycznie jest ono dokładnie przemyślaną i wystudiowaną kompozycją. Fotograf jest obserwatorem świata, wybiera odpowiedni moment, przestrzeń, które chcąc zatrzymać - fotografuje. W przypadku zdjęcia Australijska Maggie Eckardt obiektyw szerokokątny pozwala na nowatorskie uchwycenie kadru, ponieważ postać może znajdować się bardzo blisko aparatu. W latach 60 . było to zupełnie nowe spojrzenie na fotografowanie portretu. Sieff traktuje zdjęcie jako spektakl, modelki mają odgrywać wyznaczone role, niekoniecznie pokazywać swoje prawdziwe emocje:

Robienie portretu polega najczęściej na przedstawieniu twarzy lub popiersia w swojskim lub neutralnym otoczeniu. Twarz jest częścią ciała najbardziej wyeksponowaną, najbardziej widoczną, najbardziej wykorzystywaną w życiu społecznym. Twarz stała się fałszywą maską, która może wyrażać wszystko to, co się chce, która może być roześmiana, kiedy człowiek jest smutny i wyrażać zainteresowanie, gdy umiera się z nudy, może być kamienna, kiedy ponoszą nas emocje $\mathrm{e}^{24}$.

Już w połowie lat 50. Erving Goffman porównał ludzką egzystencję do „teatru życia codziennego", w którym człowiek zachowuje się jak marionetka poruszana przez sznurki, czyli innych ludzi, sytuacje życiowe, mechanizmy władzy, edukacji itd. Interakcje personalne mają charakter występu. Czasami ludzie nie są nawet świadomi, że biorą udział w społecznym spektaklu. Każda rola generuje określone normy postępowań, które jednostka powinna przestrzegać. W momencie, kiedy człowiek chce przypodobać się innym lub chce na nich wywrzeć określone wrażenie, podsuwa im wyidealizowane na różne sposoby obrazy siebie ${ }^{25}$. Modelka, pozując przed obiektywem aparatu, również zarządza wrażeniem, próbuje spełnić oczekiwania fotografa lub osoby zlecającej pracę. Tej odgrywanej scenie towarzyszą zawsze kulisy, pozostawione poza planem fotograficznym, czyli np. problemy życiowe, nadzieje, rozczarowania. Odbiorca fotografii widzi i wie tylko to, co fotograf i modelka pozwolili mu zobaczyć. Dopiero nienaturalne, teatralne

${ }^{24}$ Jeanloup Sieff 1987 Part 3, YouTube, 5.02.2011, 3:05-3:30, https://www.youtube. com /watch?v=k7B5gljIKZo [dostęp: 14.05.2019]; tłumaczenie własne - A.P.

25 Zob. E. Goffman, Człowiek w teatrze życia codziennego, tłum. H. Datner-Śpiewak, oprac. i wstęp J. Szacki, Warszawa 2008. 
gesty sugerują istnienie ukrytej głębi przedstawienia i jednocześnie ludzkiej egzystencji. Również narzędzie perspektywiczne wprowadza grę przedstawień wizualnych i samej modelki i wciąga w tę rozgrywkę także widza. Nagromadzenie powtarzających się układów wizualnych służy spotęgowaniu reakcji odbiorczej, a nawet zaangażowaniu w przedstawianie. Wyraźnie widoczne linie wprowadzone są przez balustradę, schody, przeszklone okna czy ułożenie sylwetek. Dzięki tym zabiegom oraz zróżnicowaniu bieli i czerni fotograf uzyskuje wrażenie trójwymiarowości. Mały fragment rzeczywistości nabiera kluczowego znaczenia i staje się w efekcie narzędziem marketingowym. Odbiorca powinien poczuć potrzebę posiadania tego właśnie ubrania w grochy, które, mimo że zostało umieszczone na drugim planie a może właśnie dlatego - przykuwa jego uwagę.

Sieff używa perspektywy jako narzędzia w akcie komunikacji wizualnej i dzięki niej uzyskuje wrażenie głębi oraz iluzję trzeciego wymiaru na powierzchni zdjęcia. Perspektywa pozwala również na tworzenie wielorakich systemów znaczeniowych, staje się formą symboliczną (E. Panofsky). Warto podkreślić, że narzędzie perspektywy oddziałuje najlepiej na odbiorcę, kiedy wprowadza go w rodzaj gry percepcyjnej i dalej - interpretacyjnej. Na pierwszym zdjęciu Sieffa Mode lointaine użycie perspektywy żabiej pozwala na ciekawe operowanie liniami i różnorodnymi kątami: ostrymi, prostymi, rozwartymi. Ten zabieg wciąga widza w pewien rodzaj rozgrywki komunikacyjnej i poznawczej, która rodzi potrzebę konsumencką. Na drugiej fotografii perspektywa żabia pozwala na zbudowanie dystansu między widzem a przedstawioną postacią. Im zaprezentowane ubranie wydaje się bardziej nieosiągalne, tym większą podsyca odbiorczą potrzebę posiadania właśnie tego stroju. Perspektywa żabia służy w tym przypadku jako narzędzie do celów semantycznych i sprzedażowych, dodatkowo pozwala kobietom utożsamić się z modelką oraz zaangażować w ważne kwestie społeczne. Na trzecim zdjęciu, Courrèges, fondation Maeght, narzędzie perspektywy umożliwia przypisanie fotografii warstwy semantycznie dychotomicznej, emocjonalnej i wreszcie komercyjnej. Perspektywa ukośna sprawia, że widz zostaje niejako na siłę wciągnięty w świat przedstawiony. Staje się niezauważalnym uczestnikiem przestrzeni i czasu fotograficznego. Na ostatnim obrazie, Australian Maggi Eckardt, przy udziale perspektywy wykreowano 
grę planów, która pozwala na jeszcze większe zaangażowanie odbiorcy w interpretację zdjęcia. Tonacja czarno-biała, narzędzie perspektywiczne, mocno zróżnicowane natężenie światła: wszystkie te komponenty przedstawienia budują zjawisko kontrastu, które raz wciąga w przedstawienie, innym razem dystansuje względem niego. W pierwszym przypadku kontrast wizualny inicjuje odbiorcze uczestnictwo, wywołuje potrzebę posiadania ubrania podobnego do tego, które nosiła modelka. W drugim przypadku kontrast oddala ubranie, czyniąc je tym samym mocno pożądanym. Za każdym razem wymiar komercyjny jest skutecznie osiągany.

Podsumowując, analizowane fotografie mody okazały się bardzo dobrym obiektem badawczym. Z jednej strony zdjęcia przywołały uwarunkowania kulturowe i społeczne, z drugiej - same je współtworzyły. Pobierały i wysyłały ukryte komunikaty. Można przyjąć za Flusserem, że obrazy Sieffa tworzyły globalną jedność, wytwarzały uniwersum fotograficzne, które programowało w odbiorcach określone sposoby myślenia, odczuwania i poznawania świata ${ }^{26}$. Artysta, dzięki technice obiektywu szerokokątnego, osiągał ciekawe ujęcia perspektywiczne, które zrewolucjonizowały rynek fotografii mody. Twórca wyszedł poza standardy, był odważny i nieszablonowy, dlatego pozostawił niezaprzeczalny ślad w historii fotografii mody. Narzędzie perspektywiczne - stosowane w sposób innowacyjny - z jednej strony akcentowało najważniejsze punkty zdjęcia, czyli wprowadzało jednoznaczną denotację, z drugiej pozwalało na budowanie wielorakich konotacji. Konstruowało zarówno realistyczne powierzchniowe przedstawienia, jak i surrealistyczne, głębokie konteksty. W pierwszym przypadku odbiorca był wciągany automatycznie w obraz, w drugim - zaintrygowany sam wchodził w przedstawienie. Obrazy informowały o świecie, ale przede wszystkim konstruowały alternatywną rzeczywistość, która miała wyzwolić widza $\mathrm{z}$ banalności istnienia. Udowodniono zatem wstępną hipotezę, że perspektywa jest narzędziem budującym skuteczną komunikację. Zróżnicowane, ale jednak mocno automatyczne urządzenie kodujące pozwalało fotografowi na nadawanie/kreowanie wielu historii, natomiast odbiorcy wskazywało jedno-

${ }^{26}$ Zob. V. Flusser, op. cit., s. 63. W następstwie tej teorii autor stawiał pytanie o wolność człowieka. Sam uważa, że jest ona ograniczana przez mechanikę, a ratunkiem dla owej wolności jest myślenie nielinearne, oparte na „strukturze cybernetycznej". 
znaczną denotację lub wielorakie kierunki interpretacji obrazu. Perspektywa czytana mogła być i dosłownie, i symbolicznie. Integrowała wymiar marketingowy i artystyczny. Okazała się w efekcie skutecznym narzędziem komunikacyjnym, z jednej strony wielopoziomowo uwarunkowanym, z drugiej - warunkującym określone wzorce i przekonania społeczno-kulturowe.

Wszystkie fotografie wykorzystane w tekście pochodza ze strony: https:// jeanloupsieff.com/photos.php [dostęp: 7.04.2019]. Składam serdeczne podziękowania dla Pani Barbary Siefforaz jej córki, Soni Sieff, za zgodę na nieodpłatne wykorzystanie zdjęć Jeanloupa Sieffa.

\section{Bibliografia}

Jan Białostocki, Pięć wieków myśli o sztuce. Studia i rozprawy z dziejów teorii i historii sztuki, PWN, Warszawa 1959.

Małgorzata Bogunia-Borowska M., Fotospołeczeństwo. Społeczno-kulturowe konteksty dyskursu o społeczeństwie, [w:] Fotospołeczeństwo. Antologia tekstów z socjologii wizualnej, red. M. Bogunia-Borowska, P. Sztompka, Społeczny Instytut Wydawniczy Znak, Kraków 2012.

Ernst Cassirer, Esej o człowieku. Wstęp do filozofii kultury, tłum. A. Staniewska, przedm. B. Suchodolski, Czytelnik, Warszawa 1998.

Vilém Flusser, Ku filozofii fotografii, tłum. J. Maniecki, przedm. P. Zawojski, Aletheia, Warszawa 2015.

Piotr Francuz, Głębia, [w:] idem, Imagia. W kierunku neurokognitywnej teorii obrazu, Wydawnictwo Naukowe KUL, Lublin [cop. 2013].

Erving Goffman, Człowiek w teatrze życia codziennego, tłum. H. Datner-Śpiewak, oprac. i wstęp J. Szacki, Aletheia, Warszawa 2008.

Jeanloup Sieff: 40 Years of Photography; 40 Jahre Fotographie; 40 ans de photographie, ed. S. Philippi, Taschen, Kolonia 2010.

Mały słownik terminów plastycznych, red. K. Zwolińska, Z. Malicki, Wiedza Powszechna, Warszawa 1975.

Myśliciele, kronikarze i artyści o sztuce. Od starożytności do 1500 r., wyb. i oprac. J. Białostocki, PWN, Warszawa 1978.

Erwin Panofsky, Perspektywa jako "forma symboliczna", tłum., wstęp i posłowie G. Jurkowlaniec, Wydawnictwo Uniwersytetu Warszawskiego, Warszawa 2008 . 
Słownik terminologiczny sztuk pięknych, red. K. Kubalska-Sulkiewicz, M. Bielska-Łach, A. Manteuffel-Szarota, Wydawnictwo Naukowe PWN, Warszawa 2005.

Susan Sontag, The Eye of Avedon, „Vogue” (UK) 1978, Vol. 9.

François Soulages, Estetyka fotografii. Strata i zysk, tłum. B. Mytych-Forajter, W. Forajter, TAiWPN Universitas, Kraków 2012.

Boris Uspienski, Poetyka kompozycji. Struktura tekstu artystycznego i typologia form kompozycji, tłum. P. Fast, Wydawnictwo Naukowe „Śląsk”, Katowice 1997.

\section{Źródła internetowe}

Jeanloup Sieff 1987. Part 1, https://www.youtube.com/watch?v=v4Pm9aN_JIQ. Jeanloup Sieff 1987. Part 3, https://www.youtube.com/watch?v=k7B5gljIKZo.

\section{A Perspective as a Communication Tool. Jeanloupe Sieff's Fashion Photographs}

The aim of the article is to confirm the assumption that perspective is one of the tools that build a photographic act of communication. It has been observed that the perspective allows to obtain the illusion of the third dimension on the two-dimensional surface of the photograph but also creates multiple systems of meaning and even becomes a symbolic form. The focus was on the works of Jeanloupe Sieff, a photographer who used a perspective tool in an innovative way that allowed him to create both realistic, 'superficial' presentations and surrealistic, 'deep' meaning contexts.

Keywords: perspective in photography, fashion photography, Jeanloup Sieff 